\title{
Seabed Variability and Its Influence on Acoustic Prediction Uncertainty
}

\author{
PI: James P.M. Syvitski, \\ INSTAAR, Univ. of Colorado, $156030^{\text {th }}$ St., Boulder CO, 80309-0450 \\ phone: (303) 492-7909 fax: (303) 492-3287 email: james.syvitski@ colorado.edu
}

Award Number: N000149511281

\section{LONG-TERM GOALS}

Assess and mitigate uncertainty in the tactical naval environment, in terms of accurate acoustic detection with specific reference to geoacoustics through two overarching goals:

1. Assess and characterize seafloor variability in shelf environments

2. Determine the impact of the seafloor variability on acoustic prediction uncertainty.

\section{OBJECTIVES}

1) Determine the uncertainty related to the natural variability in the environmental parameters that drive the modular modeling approach of 2D-SedFlux (primitive geological parameters). These include ocean climate and the sediment supply to the ocean margin from land. Of interest is how this variability couples with, or is independent of, model error (numerical, prediction-precision, and accuracy), in terms of local and regional characterization of uncertainty of properties of seafloor of continental margins.

2) Provide 2 D-SedFlux realizations in areas of interest to the seafloor geoacoustic team (Pratson, Holland). These realizations provide the sampling field from which Goff will sample via Monte Carlo or other statistical techniques in order to conduct uncertainty experiments. The realizations provide data sets for seismic convolution experiments (Pratson), inverse experiments (Holland), propagation experiments (Odom) and reverberation experiments (LePage). Convolve the SedFlux output with known calibrated source signatures, for studies of attenuation and scattering. SedFlux runs provide information on seafloor layering (bed coherency, bed attributes), likely location of sub-seafloor gas, proxies of seafloor roughness (ripples vs. sediment waves), and high porosity vs. low porosity zones.

3) Introduce the concept of uncertainty to the ONR-Geoclutter Modeling group to provide information on uncertainty related to false-target acquisition to our seafloor geoacoustic team. This effort would explore seafloor uncertainty related to the estimate of the location of buried channels, morphology and orientation of these channels.

4) Determine which continental margins, presently of interest to the operational Navy, would/could experience seasonal or inter-annual changes in the nature of its seafloor properties through the impact of events (earthquakes, ocean storms, river floods). 


\section{Report Documentation Page}

Form Approved

OMB No. 0704-0188

Public reporting burden for the collection of information is estimated to average 1 hour per response, including the time for reviewing instructions, searching existing data sources, gathering and maintaining the data needed, and completing and reviewing the collection of information Send comments regarding this burden estimate or any other aspect of this collection of information,

including suggestions for reducing this burden, to Washington Headquarters Services, Directorate for Information Operations and Reports, 1215 Jefferson Davis Highway, Suite 1204, Arlington

VA 22202-4302 Respondents should be aware that notwithstanding any other provision of law, no person shall be subject to a penalty for failing to comply with a collection of information if it

does not display a currently valid OMB control number

\begin{tabular}{|c|c|c|}
\hline $\begin{array}{l}\text { 1. REPORT DATE } \\
\mathbf{3 0} \text { SEP } 2001\end{array}$ & 2. REPORT TYPE & $\begin{array}{l}\text { 3. DATES COVERED } \\
\mathbf{0 0 - 0 0 - 2 0 0 1} \text { to } 00-\mathbf{0 0 - 2 0 0 1}\end{array}$ \\
\hline \multirow{3}{*}{\multicolumn{2}{|c|}{$\begin{array}{l}\text { 4. TITLE AND SUBTITLE } \\
\text { Seabed Variability and Its Influence on Acoustic Prediction Uncertainty }\end{array}$}} & 5a. CONTRACT NUMBER \\
\hline & & 5b. GRANT NUMBER \\
\hline & & 5c. PROGRAM ELEMENT NUMBER \\
\hline \multirow{3}{*}{\multicolumn{2}{|c|}{ 6. AUTHOR(S) }} & 5d. PROJECT NUMBER \\
\hline & & 5e. TASK NUMBER \\
\hline & & 5f. WORK UNIT NUMBER \\
\hline \multicolumn{2}{|c|}{$\begin{array}{l}\text { 7. PERFORMING ORGANIZATION NAME(S) AND ADDRESS(ES) } \\
\text { INSTAAR, Univ. of Colorado,,1560 30th St.,Boulder,,CO, } 80309\end{array}$} & $\begin{array}{l}\text { 8. PERFORMING ORGANIZATION } \\
\text { REPORT NUMBER }\end{array}$ \\
\hline \multirow{2}{*}{\multicolumn{2}{|c|}{ 9. SPONSORING/MONITORING AGENCY NAME(S) AND ADDRESS(ES) }} & 10. SPONSOR/MONITOR'S ACRONYM(S) \\
\hline & & $\begin{array}{l}\text { 11. SPONSOR/MONITOR'S REPORT } \\
\text { NUMBER(S) }\end{array}$ \\
\hline
\end{tabular}

12. DISTRIBUTION/AVAILABILITY STATEMENT

Approved for public release; distribution unlimited

13. SUPPLEMENTARY NOTES

14. ABSTRACT

15. SUBJECT TERMS

16. SECURITY CLASSIFICATION OF:

\begin{tabular}{c|c|c}
$\begin{array}{c}\text { a REPORT } \\
\text { unclassified }\end{array}$ & $\begin{array}{c}\text { b ABSTRACT } \\
\text { unclassified }\end{array}$ & $\begin{array}{c}\text { c THIS PAGE } \\
\text { unclassified }\end{array}$
\end{tabular}

17. LIMITATION OF ABSTRACT

Same as

Report (SAR)

\begin{tabular}{c|l}
$\begin{array}{c}\text { 18. NUMBER } \\
\text { OF PAGES } \\
\mathbf{4}\end{array}$ & 19a. NAME OF \\
& \\
&
\end{tabular}




\section{APPROACH}

1) Using MODAS and other ocean data, and Hydrotrend discharge predictions, characterize the natural variability of the environmental forcing functions controlling the seabed at the selected sites.

2) Conduct a series of SedFlux realizations of seafloor attributes that captures the natural variability of the modern climatology, and then show how the seafloor properties would change under climate change scenarios (wetter, drier, hotter, colder). Here the emphasis is on both spatial and temporal changes in the seafloor properties.

3) Provide to the geoacoustic team, $3 \mathrm{D}$ numerically derived data that characterize a margin like the New Jersey margin, and where buried channels (sandy in a mud matrix, or muddy in a sand matrix), or surface bedforms, may dominate the subseafloor acoustic response.

4) Using SedFlux, conduct experiments to determine the impact of single events (e.g. a large 100yr flood) on the seafloor characteristics. Determine the magnitude of the change in the seafloor character, and develop a method to provide this information in some probability density function. (This set of experiments targets continental margins of the type commonly found around China, S.E. Asia, Korea, etc).

\section{WORK COMPLETED}

This project is in its very early phase. Work completed includes recoding the numerical model HydroTrend so that it is able to predict the sediment delievery to the world coastlines in a more operational manner. The previous method relied on being able to estimate the rating coefficients for the different water sources (snow and ice melt, groundwater, etc). The new method uses an algorithm based on more universally accessible drainage basin properties (soil thickness, relief, temperature, etc) and reduces model uncertainty by reducing the number of tuneable parameters. The SedFlux model has been upgraded to employ Monte Carlo sampling of the probability density distributions produced from HydroTrend simulations. Once operational, we will test the various 'type' littoral zones for their sensitivity to ocean and river storms impacting seafloor properties. A schema is being developed to track the uncertainty of model results due to a) environmental input parameters, and b) model resolution and boundary conditions. A beta version of SedFlux now predicts the geoacoustic attributes of the seafloor simulations, needed for later full convolution with acoustic source signatures.

\section{RESULTS}

This project is in its very early phase.

\section{IMPACT/APPLICATIONS}


New numerical tools are being refined to allow for predicting the general nature of seafloor morphology and the developing sediment stratigraphy. The tools are being refined to allow for simulations in the littoral zone. The tools are being coupled to acoustic models and used to assess acoustic reverberation and propagation. Because these tools are driven by environmental data they offer the promise to provide seafloor acoustical information of continental margins at the global level.

\section{RELATED PROJECTS}

ONR Geoclutter: Predicting the Distribution and Properties of Buried Submarine Topography on Continental Shelves

ONR Mine Burial: Sediment Flux to the Coastal Zone: Predictions for the Navy

ONR EuroSTRATAFORM: Modeling the Effect of Climatic and Human Impacts on Margin Sedimentation

NSF MARGINS: Experimental and Theoretical Study of Linked Sedimentary Systems

NSF MARGINS: Community Sedimentary Model Science Plan for Sedimentology and Stratigraphy.

\section{PUBLICATIONS}

Morehead, M., Syvitski, J.P., Hutton, E.W.H., and Peckham, S.D. (in press) Modeling the inter-annual and intra-annual variability in the flux of sediment in ungauged river basins. Global and Planetary Change.

Morehead, M., Syvitski, J.P., and Hutton, E.W.H., 2001. The link between abrupt climate change and basin stratigraphy: A numerical approach. Global and Planetary Science, v. 28: 115-135.

Paola, C., J. Mullin, C. Ellis, D. C. Mohrig, J. B. Swenson, G. Parker, T. Hickson, P. L. Heller, L. Pratson, J.P.M. Syvitski, B. Sheets, N. Strong, 2001. Experimental Stratigraphy, GSA Today, July, p. 4-9.

Parsons, J.D., Bush, J., and Syvitski, J.P.M., 2001. Hyperpycnal plume formation with small sediment concentrations. Sedimentology, 48: 465-478.

Syvitski, J.P., and Hutton, E.H., 2001. 2D SEDFLUX 1.0C: An advanced processresponse numerical model for the fill of marine sedimentary basins. Computers and Geoscience 27(6); 731-754.

Syvitski, J.P.M., and Bahr, D.B., 2001. Numerical Models of Marine Sediment Transport and Deposition. Computers and Geosciences, 27(6): 617-753. 